\title{
WPŁYW AKCESJI POLSKI DO UNII EUROPEJSKIEJ NA „PRIORYTETY WSPÓŁPRACY ZAGRANICZNEJ WOJEWÓDZTW"
}

\author{
Hanna Dumała \\ Zakład Stosunków Międzynarodowych, Wydział Politologii, Uniwersytet Marii Curie-Skłodowskiej \\ e-mail: hanna.dumala@poczta.umcs.lublin.pl
}

\begin{abstract}
Streszczenie: „Priorytety współpracy zagranicznej województwa” to specjalna uchwała sejmiku zawierająca cele tej współpracy, jej kierunki geograficzne oraz deklaracje co do przystępowania do międzynarodowych zrzeszeń regionalnych. Dokument ten jest podstawą podejmowanych przez województwo inicjatyw zagranicznych i prowadzenia współpracy z regionami innych państw. Artykuł, w oparciu o analizę porównawczą pierwszych uchwał przyjętych w latach 1999-2000 i tych uchwalonych już po 2004 roku, weryfikuje hipotezę, że przystąpienie Polski do Unii Europejskiej spowodowało przynajmniej modyfikację, a w wielu przypadkach także przeorientowanie zarówno celów, jak i kierunków współpracy, a także zamierzeń co do przystępowania do stowarzyszeń międzynarodowych.
\end{abstract}

Słowa kluczowe: współpraca zagraniczna województwa, akcesja Polski do Unii Europejskiej, uchwała sejmiku, geograficzne kierunki współpracy, międzynarodowe zrzeszenia regionalne

\section{WSTĘP}

Jednym z elementów transformacji, jaka dokonała się w Polsce po 1989 roku, jest decentralizacja władzy oraz związane z nią swoiste uspołecznienie polityki zagranicznej państwa. Wyraża się ono w możliwościach podejmowania przez samorządy terytorialne wszystkich szczebli różnorakich inicjatyw zagranicznych i prowadzenia współpracy międzynarodowej. Prawo to zostało przyznane jednostkom terytorialnym na mocy art. 172 Konstytucji z 2 kwietnia 1997 roku, który stanowi, iż ,jednostka samorządu terytorialnego ma prawo przystę-

1 Artykuł jest pisemną wersją wystąpienia podczas konferencji „Polska w Europie 19892014. 25 lat po przemianach", zorganizowanej przez Politechnikę Koszalińską w Unieściu w dniach 28-29 kwietnia 2014 roku. 
powania do międzynarodowych zrzeszeń społeczności lokalnych i regionalnych oraz współpracy ze społecznościami lokalnymi i regionalnymi innych państw". Podstawą działań samorządu regionalnego w Polsce w tym zakresie są tak zwane „Priorytety współpracy zagranicznej województwa”. Jest to specjalna uchwała, której przyjęcie jest - zgodnie z ustawą o samorządzie województwa z 5 czerwca 1998 roku - obowiązkiem i jednocześnie wyłączną kompetencją sejmiku każdego województwa. Priorytety uchwalane są za zgodą ministra spraw zagranicznych ${ }^{2}$.

Przystąpienie Polski do Unii Europejskiej 1 maja 2004 roku niewątpliwie postawiło województwa w nowej sytuacji polityczno-społeczno-gospodarczej. W większości województw uznano, że uchwalone kilka lat wcześniej dokumenty w dużym stopniu się zdezaktualizowały ${ }^{3}$, ale w efekcie sejmiki zastosowały dwa różne rozwiązania.

1. Zdecydowana większość sejmików (13 z 16) uchyliła pierwotne uchwały o priorytetach i przyjęła zupełnie nowe. Najwcześniej, bo już w 2004 roku, uczyniło to województwo małopolskie. W uzasadnieniu napisano wprost, że „najważniejszym wydarzeniem pociągającym za sobą konieczność ponownego określenia priorytetowych celów współpracy międzynarodowej województwa jest wstąpienie Rzeczypospolitej Polskiej do Unii Europejskiej z dniem 1 maja 2004 r." ". Województwo dolnośląskie dokonało tego w 2005 roku ${ }^{5}$, rok później zaś województwa: mazowieckie ${ }^{6}$, podlaskie ${ }^{7}$ i warmińsko-mazurskie ${ }^{8}$. W kolejnych latach nowe uchwały podjęły województwa: opolskie w 2007 roku $^{9}$, podkarpackie ${ }^{10}$, pomorskie ${ }^{11}$ i zachodniopomorskie ${ }^{12}$

2 Art. 18 pkt 13 oraz rozdział 6 Ustawy (Współpraca zagraniczna). Dz. U. 1998, nr 91, poz. 576. Tekst jednolity: Dz. U. 2016, poz. 486.

3 Trzeba jednak zaznaczyć, że niektóre samorządy dokonały pierwszych (zazwyczaj niewielkich) nowelizacji jeszcze w trakcie trwania I kadencji (1998-2002). Uczyniły to na przykład: warmińsko-mazurskie w sierpniu 2002 roku (uchwała XXXIX/560/02) oraz wielkopolskie - w lipcu 2001 roku (uchwała XXXVIII/572/2001) oraz w kwietniu 2002 roku (uchwała XLVIII/702/2002). Śląskie modyfikowało „Priorytety...” aż czterokrotnie - w styczniu 2002 roku (uchwała I/46/5/2002), w maju 2002 roku (uchwała I/50/1/2002), w październiku 2002 roku (uchwała I/57/12/2002) oraz w styczniu 2004 roku (uchwała II/16/2/2004).

4 Uchwała nr XXIII/314/04 Sejmiku Województwa Małopolskiego z dnia 30 sierpnia 2004 roku.

5 Uchwała nr XLVII/625/2005 Sejmiku Województwa Dolnośląskiego z dnia 27 października 2005 roku.

${ }^{6}$ Uchwała nr 27/06 Sejmiku Województwa Mazowieckiego z dnia 18 grudnia 2006 roku.

7 Uchwała nr XXXVII/480/06 Sejmiku Województwa Podlaskiego z dnia 10 kwietnia 2006 roku.

8 Uchwała nr XLIII/588/06 Sejmiku Województwa Warmińsko-Mazurskiego z dnia 25 kwietnia 2006 roku.

9 Uchwała nr VII/51/2007 Sejmiku Województwa Opolskiego z dnia 24 kwietnia 2007 roku.

10 Uchwała nr XVIII/283/08 Sejmiku Województwa Podkarpackiego z dnia 28 stycznia 2008 roku.

11 Uchwała nr 463/XXII/08 Sejmiku Województwa Pomorskiego z dnia 26 maja 2008 roku.

12 Uchwała nr XXVI/269/08 Sejmiku Województwa Zachodniopomorskiego z dnia 2 grudnia 2008 roku. 
w 2008 roku, śląskie w 2009 roku $^{13}$, a lubuskie ${ }^{14}$, tódzkie $^{15}$ i świętokrzyskie ${ }^{16}$ dopiero w 2010 roku, czyli 6 lat po akcesji.

2. Sejmiki dwóch województw: lubelskiego i wielkopolskiego dokonały jedynie mniej lub bardziej istotnych modyfikacji treści poprzednich uchwał: województwo lubelskie w 2005 roku $^{17}$, a wielkopolskie w 2006 roku $^{18}$.

Wyjątkowym przypadkiem jest natomiast decyzja samorządu województwa kujawsko-pomorskiego, który pozostawił uchwałę w jej pierwotnej wersji z roku $2000^{19}$.

Celem artykułu jest udzielenie odpowiedzi na pytanie, czy i w jaki sposób przystąpienie Polski do Unii Europejskiej wpłynęło na treść „Priorytetów...”. Służyć temu będzie analiza porównawcza pierwotnych, pochodzących z przełomu lat 1999/2000, uchwał sejmików wojewódzkich nt. priorytetów współpracy zagranicznej z treścią analogicznych dokumentów uchwalonych bezpośrednio po 2004 roku $^{20}$. Jest to więc wyłącznie analiza warstwy deklaratywnej, a nie rzeczywistego stanu współpracy zagranicznej realizowanej przez polskie regiony. W artykule dokonano przeglądu „Priorytetów...” w trzech aspektach, odzwierciedlających ich nieodzowną, wynikającą z ustawy, treść: 1) cele współpracy, 2) jej kierunki geograficzne oraz 3) zamierzenia co do przystępowania do międzynarodowych zrzeszeń regionalnych.

Jak wynika z przedstawionej wyżej sytuacji, wstąpienie Polski do Unii Europejskiej nie dla wszystkich samorządów wojewódzkich było wystarczającym powodem do dokonania gruntownej rewizji celów i kierunków współpracy zagranicznej. Jednocześnie w przypadku kilku województw zmiany w „Priorytetach..." nie zostały dokonane bezpośrednio po akcesji ${ }^{21}$, co wskazuje, że powo-

${ }^{13}$ Uchwała sejmiku nr III/38/1/2009 z dnia 20 maja 2009 roku.

${ }^{14}$ Uchwała nr LII/525/2010 Sejmiku Województwa Lubuskiego z dnia 14 czerwca 2010 roku.

${ }^{15}$ Uchwała nr LIX/1614/10 Sejmiku Województwa Łódzkiego z dnia 24 sierpnia 2010 roku.

${ }^{16}$ Uchwała nr XLI/731/10 Sejmiku Województwa Świętokrzyskiego z dnia 27 września 2010 roku.

${ }^{17}$ Uchwała nr XII/133/99 Sejmiku Województwa Lubelskiego z dnia 30 sierpnia 1999 roku zmieniona uchwałą nr XXXIII/454/05 z dnia 25 kwietnia 2005 roku.

${ }^{18}$ Uchwała nr XVI/176/99 Sejmiku Województwa Wielkopolskiego z dnia 8 listopada 1999 roku zmieniona uchwałą nr L/827/06 z dnia 17 lipca 2006 roku. Całkowicie nową uchwałę Sejmik przyjął dopiero w 2013 roku. Uchwała nr XXXVII/739/13 z 30 września 2013 roku.

${ }^{19}$ Uchwała nr 409/2000 Sejmiku Województwa Kujawsko-Pomorskiego z dnia 12 czerwca 2000 roku.

${ }^{20}$ Brane jest pod uwagę brzmienie uchwał w pierwszej wersji przyjętej po 2004 roku, niezależnie od ich późniejszych ewentualnych modyfikacji.

${ }^{21}$ Przy czym należy pamiętać, że proces uchwalania tego dokumentu ma kilka faz: przyjęty przez sejmik projekt jest przesyłany do MSZ celem akceptacji i po uzyskaniu takowej (lub ewentualnych uwagach) przyjmowany w brzmieniu ostatecznym. Tak więc między projektem a właściwą uchwałą mija kilka, a nawet kilkanaście miesięcy. Na przykład w przypadku województwa pomorskiego Sejmik przyjął projekt uchwały w grudniu 2007 roku, minister spraw zagranicznych wyraził zgodę w marcu 2008 roku, a ostateczny tekst uchwały został przyjęty w maju 2008 roku, czyli proces ten trwał pół roku. 
dów uchwalenia nowych dokumentów było więcej niż tylko sam fakt wstąpienia do UE (na przykład rozpoczęcie nowej kadencji sejmików w 2006 roku), choć mógł być to czynnik istotny, a nawet pierwszoplanowy. Wskazały nań - poza Małopolską - także m.in. województwa: opolskie - „[...] członkostwo Polski w Unii Europejskiej oznacza [...] dla Województwa nową jakościowo sytuację", pomorskie - ,[...] od tego czasu [1999 rok] wystąpiły jednak nowe warunki w realizacji współpracy zagranicznej [...] związane m.in. z: 1) przystąpieniem Polski do Unii Europejskiej”, mazowieckie - „Wraz z wejściem Polski do Unii Europejskiej zaistniała konieczność przygotowania nowych »Priorytetów współpracy zagranicznej Województwa Mazowieckiego« odnoszących się do nowej sytuacji prawnej i międzynarodowej Polski. Treść nowego dokumentu uwzględnia nową rolę Polski jako państwa członkowskiego Unii Europejskiej [...]”, a także świętokrzyskie - „Najważniejszym czynnikiem pociągającym za sobą konieczność aktualizacji priorytetów współpracy zagranicznej Województwa jest przystąpienie Rzeczypospolitej Polskiej do Unii Europejskiej z dniem 1 maja 2004 roku". Województwo dolnośląskie uznało, że ,aktualizacja potrzebna jest również [podkreślenie - H. D.] ze względu na fakt przystąpienia Polski do Unii Europejskiej”.

\section{GŁÓWNE CELE WSPÓŁPRACY ZAGRANICZNEJ}

Liczba deklarowanych w uchwałach celów współpracy zagranicznej jest bardzo różna: od kilku do kilkunastu, co wyraża znacząco różny stopień ich szczegółowości. Dodatkowo obraz komplikuje fakt, że to, co niektóre sejmiki uznały za cel współpracy, inne potraktowały jako instrument realizacji innych celów ${ }^{22}$.

We wszystkich analizowanych uchwałach współpraca międzynarodowa uznana została - wprost lub w sposób pośredni - za instrument społeczno-gospodarczego i kulturowego rozwoju regionu. Samorządy stwierdzają między innymi, że współpraca zagraniczna jest jednym z instrumentów „kreowania harmonijnego rozwoju gospodarczego, kulturalnego i społeczno-politycznego" (dolnośląskie), „wszechstronnego rozwoju województwa” (śląskie), „tworzenia warunków rozwoju gospodarczego regionu jako drogi do dobrobytu ludności” (kujawsko-pomorskie), ,jedną z najważniejszych form aktywności samorządu w kształtowaniu zrównoważonego rozwoju ekonomicznego regionu" (małopolskie), a podstawowym kryterium nawiązywania współpracy z partnerami zagranicznymi jest „osiągnięcie pozytywnego wpływu na rozwój społeczno-gospodarczy województwa" (podlaskie), „tworzenie korzystnych warunków aktywizacji kapitału rodzimego oraz przyciąganie kapitału zagranicznego" (łódzkie) czy też kształtowanie „gotowości do sprostania wyzwaniom, jakie stawia przez Polską członkostwo w Unii

${ }^{22}$ Patrz także: H. Dumała, Priorytety wspólpracy zagranicznej polskich województw - analiza porównawcza, [w:] Polska Wschodnia. Determinanty rozwoju, B. Plago (red.), Białystok 2006, s. 893-906. 
Europejskiej i problemy globalizacji” (małopolskie). Deklarują zdecydowane rozwijanie współpracy ,z wybranymi regionami Europy, Azji i Stanów Zjednoczonych i w ten sposób przyczynia[nie] się do wzajemnego postępu gospodarczego i społecznego regionów współpracujących" (zachodniopomorskie).

Do najczęściej deklarowanych celów współpracy zagranicznej należą: przyspieszenie wzrostu gospodarczego (lubuskie) oraz wspólne z partnerami zagranicznymi działania na rzecz zrównoważonego rozwoju regionu (lubelskie, podkarpackie) i rozwiązywania problemów rozwojowych (dolnośląskie). Mają być podejmowane w takich dziedzinach, jak: modernizacja i rozbudowa infrastruktury drogowej, morskiej, rzecznej, lotniczej oraz telekomunikacji, a także infrastruktury technicznej w zakresie ochrony środowiska naturalnego, rozwój obszarów wiejskich, rozwój małej i średniej przedsiębiorczości, edukacja, oświata, szkolnictwo wyższe i współpraca uniwersytetów, turystyka, ochrona zdrowia i opieka społeczna, zrównoważona gospodarka wodna. W pewnych wypadkach w uchwałach wymieniono konkretne przedsięwzięcia i inwestycje, które wymagają współdziałania z partnerami zagranicznymi. Tak na przykład dla województwa dolnośląskiego szczególnie ważna była budowa autostrady A4, która stanowi fragment połączenia Wschód-Zachód (trasa od Paryża przez Drezno, Wrocław, Kraków i Lwów do Kijowa), rozbudowa towarowego przejścia granicznego z Czechami Lubawka-Kralowec i zagospodarowanie rzeki Odry, a dla podlaskiego - Via Baltica, kanał augustowski i parki technologiczne.

Interesujące jest to, że Wielkopolska na pierwszym miejscu umieściła nie rozwój gospodarczy, lecz „rozwijanie demokracji lokalnej i regionalnej poprzez wymianę doświadczeń z zakresu teorii i praktyki funkcjonowania administracji publicznej". Wysoko w hierarchii celów kwestia ta znalazła się również w uchwale województwa śląskiego, sformułowana jako trzeci z kolei cel: „pozyskiwanie wiedzy i doświadczeń w zarządzaniu regionem [...]”.

Istotnym celem, wskazywanym przez większość sejmików, było przygotowanie regionu do integracji z Unią Europejską (m.in. mazowieckie, podkarpackie, śląskie). Wpisuje się w to także promocja regionu poza granicami Polski (lubelskie, mazowieckie, śląskie), w tym zwłaszcza na forum instytucji i organizacji europejskich, co ma służyć pozyskiwaniu kapitału, nowoczesnej technologii i inwestorów gotowych współuczestniczyć w przedsięwzięciach na rzecz rozwoju województwa, ale także zwiększaniu roli i znaczenia regionów w strukturach międzynarodowych (kujawsko-pomorskie, małopolskie, pomorskie).

W uchwałach przyjętych po 2004 roku nie nastąpiła zasadnicza zmiana wcześniej deklarowanych celów współpracy zagranicznej województw, pojawiły się natomiast nowe cele wynikające $\mathrm{z}$ już osiągniętego członkostwa Polski w Unii Europejskiej. W związku z tym mowa jest nie tylko o zrównoważonym rozwoju regionu, ale również o „spójności ekonomicznej, społecznej i terytorialnej” (warmińsko-mazurskie), „lepszym wykorzystaniu możliwości rozwojowych wynikających z tego członkostwa" i ,wspieraniu realizowanych przez podmioty [...] projektów finansowanych ze środków programów Unii Europejskiej” (dolnoślą- 
skie, podlaskie). Województwo podkarpackie jako cel wskazuje „podejmowanie działań z regionami państw Unii Europejskiej i regionami innych państw w zakresie wspólnego wykorzystania funduszy unijnych” oraz „nawiązanie i rozwój kontaktów województwa [...] z instytucjami Wspólnot Europejskich” poprzez swoje biuro w Brukseli. Województwo warmińsko-mazurskie zaś podkreśla, że „regionalna współpraca międzynarodowa przynosi wartość dodaną, która stanowi podstawę budowy wspólnego europejskiego domu".

\section{GEOGRAFICZNE KIERUNKI WSPÓŁPRACY}

Pierwotne uchwały zawierały dość rozbudowane listy kierunków współpracy, liczące kilkanaście, a nawet kilkadziesiąt pozycji (szczegóły patrz tabela 1). „Priorytety...” zawierały bowiem deklaracje odnośnie do kierunków współpracy zarówno dopiero planowanej, jak i kontynuowanej (obejmowały kontakty „starych” województw, które weszły w skład województw utworzonych w wyniku reformy terytorialnej z 1998 roku). Często umieszczano w uchwałach wyłącznie nazwy państw, bez wskazywania konkretnego regionu, z którym ta współpraca mogłaby być realizowana. Skrajnym przypadkiem jest województwo mazowieckie, które pogrupowało swoich partnerów w trzech obszarach, nie wskazując nie tylko na konkretnych partnerów regionalnych, ale nawet na państwa (z wyjątkiem USA) ${ }^{23}$. Brak wyraźnie sprecyzowanej polityki międzynarodowej (przynajmniej niektórych województw) widać było również w braku uporządkowania i hierarchizacji kierunków geograficznych, choć w przypadku województw przygranicznych często stosowano podział kontaktów na transgraniczne (sąsiedzkie) i regionalne (dolnośląskie, lubuskie).

W uchwałach z przełomu lat 1999/2000 uznawano w pierwszym rzędzie za priorytetowe te kierunki współpracy, które służyć miały przygotowaniu Polski do członkostwa w Unii Europejskiej i intensyfikacji procesu integracji Polski z UE. Podkreślano, że w realizacji wymienionych wyżej celów i zadań istotną rolę odgrywa możliwość wykorzystania doświadczeń w wykorzystywaniu funduszy strukturalnych. Stąd też w pełni uzasadniony był wybór jako partnerów współpracy przede wszystkim regionów państw członkowskich i stowarzyszonych z UE, to one bowiem takie doświadczenie posiadały. W konsekwencji w analizowanych uchwałach sejmików z przełomu lat 1999/2000 przeważają państwa/regiony kontynentu europejskiego, w tym przede wszystkim państwa określane jako zachodnioeuropejskie lub członkowskie Unii Europejskiej. Znalazły się w nich wszystkie (15) państwa ówczesnej Unii Europejskiej, wybierane jednak z różnym nasileniem.

Wśród unijnych partnerów współpracy najczęściej wybierano trzy kierunki: Republikę Federalną Niemiec, Francję i Włochy. Wskazały na nie wszystkie

${ }^{23}$ Były to: kraje UE, zwłaszcza sąsiedzkie; Europa Środkowa i Wschodnia; oraz państwa członkowskie OECD, w tym zwłaszcza Stany Zjednoczone. 
(poza wcześniej wspomnianym mazowieckim) województwa. W przypadku Niemiec wymieniono niemal wszystkie (poza Saksonią Anhalt) kraje związkowe, najczęściej wybierano jednak: Bawarię, Berlin, Brandenburgię i Saksonię (po 4 razy) oraz Badenię-Wirtembergię i Dolną Saksonię (po 3 razy). Z Francji najchętniej wybierano Alzację, którą wymieniono trzykrotnie, wskazano także (zazwyczaj raz) 11 innych regionów (z 22) i 6 departamentów. W przypadku Włoch wymieniono łącznie 12 (z 20) regionów tego kraju i 2 prowincje. W tym przypadku brak jest wyraźnego lidera - najwyższa liczba wskazań to $2^{24}$.

Po roku 2004 Republika Federalna Niemiec i jej kraje związkowe pojawiają się również we wszystkich uchwałach, ale liczba partnerów z Niemiec spada (patrz tabela 1). Na pierwsze miejsce wysunęła się Brandenburgia z sześcioma wskazaniami, a pozycję drugą z czterema wskazaniami zajęła Bawaria. Także w przypadku Francji liczba wskazań tego kierunku współpracy spadła (zrezygnowało świętokrzyskie) i częściej wymieniano po prostu Francję, a żaden z regionów czy departamentów nie był wskazany więcej niż raz. Analogiczna sytuacja istnieje w odniesieniu do Włoch - liczba wskazań jest niższa (zrezygnowało z włoskiego kierunku współpracy województwo śląskie, a województwa podkarpackie i lubelskie nie wskazały żadnego konkretnego regionalnego partnera), jedynie dwa regiony wybrane zostały częściej niż raz: Liguria i Emilia Romagna (po 2 razy). Można więc domniemywać, że nie wszystkie zakładane pierwotnie kierunki współpracy udało się z powodzeniem podjąć, w związku z czym zrezygnowano z ich utrzymywania na liście priorytetów geograficznych.

Warto zauważyć, że województwa wskazywały nie tylko na jednostki terytorialne na równorzędnym sobie poziomie podziału terytorialnego - niemieckie kraje związkowe, belgijskie, francuskie i włoskie regiony, hiszpańskie wspólnoty autonomiczne, ale także na jednostki szczebla niższego - francuskie departamenty oraz belgijskie i hiszpańskie prowincje.

Jeżeli kierunki geograficzne wymieniano nie w kolejności alfabetycznej, lecz umieszczając je zgodnie z ich ważnością (hierarchią), to zazwyczaj Niemcy i ich regiony lokowano na pierwszym miejscu. Wybór krajów związkowych RFN jest argumentowany na dwa sposoby. Po pierwsze, województwa zachodnie powołują się na bezpośrednie sąsiedztwo i współpracę transgraniczną. Po drugie, niezależnie od położenia województwa, wybór związany jest z ich wysokim poziomem rozwoju, a także doświadczeniem w wykorzystywaniu europejskich środków pomocowych. W przypadku Francji i Włoch wybór regionów z tych państw jako partnerów współpracy był dość oczywisty z racji wysoko rozwiniętej gospodarki, w sytuacji kiedy głównym celem współpracy był rozwój gospodarczy województwa.

${ }^{24}$ Szerzej patrz: H. Dumała, Priorytety geograficzne wspótpracy zagranicznej polskich regionów, [w:] Regiony: Polska - Europa - świat, A. Stępień-Kuczyńska, K. Dośpiał-Borysiak (red.), Toruń 2009, s. 243-264. 
Poza wymienionymi wyżej państwami w „Priorytetach...” wskazywano także na północny wymiar Unii Europejskiej. Co ciekawe, zainteresowanie państwami nordyckimi nie uległo większej zmianie: Szwecję umieszczono zarówno w pierwszych uchwałach, jak i w tych z okresu po przystąpieniu do UE 11 razy, w przypadku Danii było to odpowiednio: 8 i 6 razy.

Do grona często wskazywanych partnerów z tzw. starej Unii dołączyła po 2004 roku również Hiszpania i Wielka Brytania (po 12 wskazań). Rozszerzenie UE w 2004 roku spowodowało, że także nasi południowi sąsiedzi, a więc Czechy i Słowacja, oraz dość popularne jako partner współpracy Węgry są członkami tej organizacji. To w oczywisty sposób znacznie powiększyło udział partnerów unijnych w nowych wersjach „Priorytetów...”.

Z państw nienależących do Unii Europejskiej na bardzo wysokim poziomie wskazań utrzymują się państwa sąsiadujące z nami na wschodzie, czyli Ukraina i Rosja. W uchwałach z lat 1999/2000 jedynie w przypadku województw dolnośląskiego i małopolskiego nie znalazła się Rosja, a w uchwale województwa wielkopolskiego - Ukraina, natomiast po 2004 roku tylko uchwała sejmiku województwa małopolskiego nie wskazała Rosji jako partnera. Nie nastąpiło więc pełne odwrócenie kierunków współpracy, a Europa Wschodnia ciągle zajmuje wśród nich drugie pod względem znaczenia miejsce.

Państwa/regiony spoza kontynentu europejskiego pojawiają się w zdecydowanej większości analizowanych uchwał (brakuje ich jedynie w obu uchwałach dolnośląskiego i wielkopolskiego, pierwszej wersji uchwał opolskiego i świętokrzyskiego oraz znowelizowanej uchwały podlaskiego), ale nie należą do kierunków pierwszoplanowych. Jednocześnie widać pewną prawidłowość: w wersjach uchwalanych po 2004 roku liczba takich pozaeuropejskich partnerów zdecydowanie spada. Najczęściej województwa widzą korzyści z nawiązania współpracy ze Stanami Zjednoczonymi Ameryki, Chinami, Japonią, Koreą, ale także pojawiają się w uchwałach na przykład państwa arabskie (lubuskie 1999). W takich przypadkach rzadko jednak wskazywano na konkretną jednostkę terytorialną.

\section{ZAMIERZENIA CO DO PRZYSTĘPOWANIA DO MIĘDZYNARODOWYCH ZRZESZEŃ REGIONALNYCH}

Część sejmików potraktowała ten punkt uchwały literalnie, wymieniając jedynie te organizacje międzyregionalne, do których województwa zamierzały przystąpić w przyszłości, inne także te, w których już były członkami i chciały to członkostwo kontynuować (szczegóły patrz tabela 2). Niektóre uchwały rozróżniają członkostwo (uczestnictwo, czynny udział) i aktywną współpracę. Nie ma też jednolitej interpretacji pojęcia „zrzeszenie”25. Spora część sejmików

${ }^{25}$ Zgodnie z ustawą o zasadach przystępowania jednostek samorządu terytorialnego do międzynarodowych zrzeszeń spoleczności lokalnych i regionalnych z 15 września 2000 roku (art. 1 ust. 2) 
zamieściła w wykazie również Komitet Regionów UE (KR) czy Kongres Władz Lokalnych i Regionalnych Rady Europy (CLRAE), podczas gdy żadne pojedyncze województwo nie może zostać wyłącznie z własnej inicjatywy członkiem tych instytucji, które mają zupełnie odrębne systemy rekrutacji ${ }^{26}$. W „Priorytetach...” jest mowa również o uczestnictwie w pracach komisji międzyrządowych, takich jak np. Komitet ds. Współpracy Przygranicznej Polski i Niemiec, Polsko-Rosyjskiej Rady ds. Współpracy Północno-Wschodnich Województw RP z Obwodem Kaliningradzkim czy w programach i projektach (np. Ars Baltica, VASAB 2010). Samorządy województw deklarują również uczestnictwo w pracach lub współpracę z działającymi na ich obszarze euroregionami.

Odrębnie potraktowały tę część „Priorytetów...” sejmiki województwa lubuskiego (w wersji z 1999 roku) i wielkopolskiego (w obu wersjach), uznając za ważną , ,aktywność Sejmiku w regionalnych organizacjach międzynarodowych”, ale nie wymieniając z nazwy żadnego konkretnego przykładu i wskazując, iż w każdym przypadku podstawą podjęcia takiej współpracy będzie stosowna uchwała Sejmiku² ${ }^{27}$.

Odrzucając te wskazania, które nie spełniają warunków uznania za międzynarodowe zrzeszenie, na podstawie analizy treści uchwał stwierdzono, że w pierwszych wersjach „Priorytetów...” wskazano jedynie na 5 zrzeszeń, w wersjach następnych liczba ta wzrosła blisko czterokrotnie - do 19.

Najczęściej wymienianym stowarzyszeniem międzynarodowym jest Zgromadzenie Regionów Europejskich (ang. Assembly of European Regions - AER). Powstałe w 1985 roku Zgromadzenie należy do największych stowarzyszeń regionalnych w Europie. W pierwszych wersjach „Priorytetów...” na AER wskazało 14 województw, a więc wszystkie, które w ogóle wymieniły z nazwy jakieś stowarzyszenie. Po roku 2004 liczba ta nieznacznie spadła do 12 (Zgromadzenie wykreślono w uchwałach trzech województw: dolnośląskiego, opolskiego, warmińsko-mazurskiego, a dopisano w uchwale jednego: lubuskiego).

Sześć województw zadeklarowało pierwotnie chęć przystąpienia do Rady Gmin i Regionów Europy (ang. Council of European Municipalities and Regions - CEMR). Jest to jednak organizacja szczególna, nie należą bowiem do niej pojedyncze jednostki terytorialne, lecz narodowe stowarzyszenia jednostek terytorial-

zrzeszeniem jest „organizacja, związek i stowarzyszenie powołane przez społeczności lokalne co najmniej dwóch państw zgodnie z ich prawem wewnętrznym”. Dz. U. 2000, nr 91, poz. 1009 z późn. zm.

${ }^{26}$ Jak wiadomo, przedstawicieli do KR mianuje Rada UE na wniosek państwa członkowskiego, a „wybrani” w ten sposób członkowie Komitetu nie mogą formalnie działać w interesie ani regionów, ani państw, z których pochodzą, lecz powinni działać niezależnie „w ogólnym interesie Wspólnoty”. Jednocześnie warto dodać, że na 21 miejsc dla Polski w KR tylko 10 zgłaszanych jest przez ogólnokrajową organizację zrzeszającą jednostki samorządu wojewódzkiego, czyli Związek Województw RP (ZWRP). Udział w pracach CLRAE jest z kolei powiązany z przynależnością do Rady Europy (RE) - każde państwo otrzymuje tyle miejsc w dwu izbach Kongresu (Izba Władz Lokalnych i Izba Regionów), ile posiada w Zgromadzeniu Parlamentarnym RE. W Izbie Regionów Polska ma więc jedynie 6 miejsc.

${ }^{27}$ Zgodnie z art. 18 pkt 14 ustawy o samorządzie województwa. 
nych danego szczebla. Zakładano, że poprzez struktury tworzącego się wówczas Związku Województw RP będzie to możliwe. Jednak ZWRP nie przystąpił do CEMR (jest w niej natomiast Związek Miast Polskich - ZMP i Związek Powiatów Polskich - ZPP), stąd też w kolejnych wersjach „Priorytetów...” zazwyczaj CEMR z uchwały usuwano - uczyniły tak województwa: łódzkie, mazowieckie, pomorskie, ale też wprowadzano -województwo lubuskie. Ostatecznie wskazania na CEMR znalazły się w „Priorytetach...” czterech województw.

Pięć przygranicznych województw zadeklarowało przystąpienie do utworzonego w 1971 roku Stowarzyszenia Europejskich Regionów Granicznych (ang. Association of European Border Regions - AEBR). Członkiem zwyczajnym Stowarzyszenia z prawem głosu może zostać region z państwa członkowskiego UE lub Rady Europy. Może nim być pojedynczy region przygraniczny, region transgraniczny (euroregion) lub porozumienie regionów granicznych z obszaru kilku państw, jeśli ich członkowie nie przystąpią do Stowarzyszenia samodzielnie. Na członkostwo - poprzez struktury euroregionalne - wskazało województwo lubelskie (Euroregion Bug), pozostałe województwa (dolnośląskie, podlaskie, pomorskie i zachodniopomorskie) nie uczyniły takiego zastrzeżenia. W późniejszych wersjach priorytetów Stowarzyszenie pojawia się czterokrotnie, z tym że województwa dolnośląskie i zachodniopomorskie zrezygnowały z wymieniania tej organizacji, natomiast dodało ją do listy województwo warmińsko-mazurskie.

Trzy województwa wskazały na Współpracę Subregionalną Państw Regionu Morza Bałtyckiego (ang. Baltic Sea States Subregional Co-operation - BSSSC) jako miejsce aktywnej działalności. Były to nadmorskie województwa pomorskie i zachodniopomorskie oraz nie- leżące nad morzem województwo podlaskie, w przypadku którego zamierzenie to wpisuje się w szerszą strategię utrzymywania kontaktów z regionami basenu Morza Bałtyckiego. Po roku 2004 do grona zainteresowanych współdziałaniem w ramach BSSSC dołączyło województwo warmińsko-mazurskie.

Ostatnią organizacją spośród wskazanych w pierwszych wersjach „Priorytetów..." była Konferencja Peryferyjnych Regionów Nadmorskich (ang. Conference of Peripherial Maritime Regions - CPMR), wymieniona jedynie w uchwale województwa pomorskiego. Konferencja pojawiła się również w uchwale z 2006 roku Sejmiku województwa podlaskiego.

Lista organizacji z uchwał przyjętych po 2004 roku jest znacznie dłuższa i obejmuje - jak już wcześniej powiedziano - 19 pozycji, z czego jednak zdecydowana większość wskazywana jest przez pojedyncze województwa (patrz tabela 2). Nowymi stowarzyszeniami są: Europejskie Regionalne Stowarzyszenie na rzecz Społeczeństwa Informacyjnego (ang. European Regional Information SocietyAssociation-ERIS@)-4 wskazania, Forum Regionów Wyszehradzkich - 2 wskazania, Międzyregionalne Porozumienie na rzecz Utworzenia Środkowoeuropejskiego Korytarza Transportowego (ang. Central European Transport Corridor-CETC) - 2 wskazania, Forum Rozwoju Bałtyku (Baltic Development Forum - BDF) - 2 wskazania oraz po jednym wskazaniu: Europejska Sieć Re- 
gionalnego Dziedzictwa Kulinarnego, Europejska Sieć Współpracy Regionów w zakresie Badań i Innowacji (ang. European Regions Research and Innovation Network - ERRIN), Europejska Wspólnota Rozwoju Obszarów Wiejskich (ARGE), Europejski Szlak Dziedzictwa Przemysłowego (ang. European Route of Industrial Heritage - ERIH), Forum Parlamentów Regionalnych Południowego Bałtyku, Platforma Monitoringu Strategii Lizbońskiej (ang. Lisbon Monitoring Platform - LMP ${ }^{28}$ ), Sieć Regionów Wschodniej Granicy Zewnętrznej (ang. Network of Eastern External Border Regions - NEEBOR), Sieć Społeczeństwa Informacyjnego w Regionach (ang. Tele Regions Network - TRN), Stowarzyszenie Europejskich Regionów Przemysłowych (ang. Association of European Regions of Industrial Technology - RETI) oraz Stowarzyszenie Odra-Dunaj-Laba.

Wszystkie nowo wskazywane organizacje i stowarzyszenia mają zasięg europejski (ogólno- lub subkontynentalny) i - jeżeli nie bezpośrednio, to pośrednio - powiązane są z działalnością Unii Europejskiej (np. korzystają z grantów UE).

\section{PODSUMOWANIE}

We wstępie artykułu zauważono, że przystąpienie Polski do Unii Europejskiej nie dla wszystkich samorządów wojewódzkich było wystarczającym powodem do przyjęcia nowych uchwał w sprawie priorytetów współpracy zagranicznej dokonało tego 13 z 16 województw. Analiza porównawcza treści pierwotnych uchwał sejmików oraz uchwał przyjętych po roku 2004 pozwala na wyciągnięcie następujących wniosków.

Po pierwsze, województwa nie dokonały istotnych zmian „Priorytetów...” w zakresie celów współpracy zagranicznej w związku z akcesją do UE. Polegały one raczej na pewnym uszczegółowieniu deklarowanych pierwotnie celów, a zadania wynikające $\mathrm{z}$ okresu przedakcesyjnego zostały zastąpione zadaniami związanymi z wykorzystaniem faktu bycia członkiem Unii Europejskiej. Podkreślano przy tym, że w ich realizacji istotne jest wykorzystanie doświadczeń regionów europejskich, zwłaszcza jeżeli chodzi o możliwości płynące z dostępnych dla Polski funduszy unijnych.

Po drugie, przystąpienie Polski do Unii Europejskiej w 2004 roku wyraźnie pogłębiło europejski kierunek współpracy zagranicznej województw. Pierwszoplanowymi partnerami są regiony państw członkowskich Unii Europejskiej, w tym zwłaszcza kraje związkowe Niemiec, regiony i departamenty Francji oraz regiony i prowincje Włoch. W dalszym ciągu jednak województwa przykładają dużą wagę także do współpracy z państwami Europy Wschodniej - Ukrainą i Rosją. Pozaeuropejskie kierunki współpracy stanowiły i nadal stanowią margines wskazań.

${ }^{28}$ Jej następcą jest Platforma Monitorowania Strategii „Europa 2020” - EUROPE2020MP. 
Po trzecie, jeżeli chodzi o zamierzenia co do przystępowania do międzynarodowych zrzeszeń regionalnych, w pierwszych wersjach „Priorytetów...” ograniczano plany z tym związane do minimum, wskazując na te struktury, do których przynależność w okresie przedakcesyjnym wydawała się najbardziej przydatna (możliwość czerpania $\mathrm{z}$ doświadczeń wykorzystywania środków pomocowych). Po roku 2004 województwa znacznie rozszerzyły swoje sformalizowane kontakty, wskazując w dalszym ciągu na zrzeszenia reprezentujące interesy ogólne, takie jak Zgromadzenie Regionów Europy czy Rada Gmin i Regionów Europy (choć z mniejszą częstotliwością), ale też w coraz większym stopniu na ugrupowania wyspecjalizowane, realizujące interesy specjalne, takie jak chociażby Europejska Sieć Regionalnego Dziedzictwa Kulinarnego czy Europejski Szlak Dziedzictwa Przemysłowego. Wydaje się, że interesy ogólne regionalnych jednostek terytorialnych w Unii Europejskiej w dużej mierze artykułowane są w ramach Komitetu Regionów, stąd też przesunięcie punktu ciężkości na struktury wyspecjalizowane, pozwalające wspólnie realizować bardzo konkretne projekty i przedsięwzięcia.

\title{
WYKAZ PIŚMIENNICTWA
}

1. Dumała H., 2009: Priorytety geograficzne współpracy zagranicznej polskich regionów. W: Regiony: Polska - Europa - świat, A. Stępień-Kuczyńska. K. Dośpiał-Borysiak (red.), Toruń, 243-264.

2. Dumała H., 2006: Priorytety współpracy zagranicznej polskich województw - analiza porównawcza. W: Polska Wschodnia. Determinanty rozwoju, B. Plago (red.), Białystok, 893-906.

3. Ustawa o samorządzie województwa. Dz. U. 1998, nr 91, poz. 576. Tekst jednolity: Dz. U. 2016, poz. 486.

4. Ustawa o zasadach przystępowania jednostek samorządu terytorialnego do międzynarodowych zrzeszeń społeczności lokalnych i regionalnych. Dz. U. 2000, nr 91, poz. 1009 z późn. zm.

\section{THE IMPACT OF POLISH ACCESSION TO THE EUROPEAN UNION ON PRIORITIES OF}

\section{EXTERNAL COOPERATION OF VOIVODESHIPS}

\begin{abstract}
The priorities of external cooperation of voivodeship" is a special resolution of sejmik, that includes targets of cooperation, their geographical direction, and statements regarding the accession to international associations of regions. This document is the basis for foreign initiatives undertaken by the voivodeships to cooperate with regions in other countries. The article, based on a comparative analysis of the first resolutions adopted in 1999-2000 and those enacted after 2004, verifies the assumption that Polish accession to the European Union resulted in at least modifying, and in many cases reorienting, both the goals and the direction of cooperation as well as plans to join international associations.
\end{abstract}

Key words: external cooperation of vojevodeship, Polish accession to the European Union, the resolution of sejmik, geographical directions of cooperation, the international associations of regions 


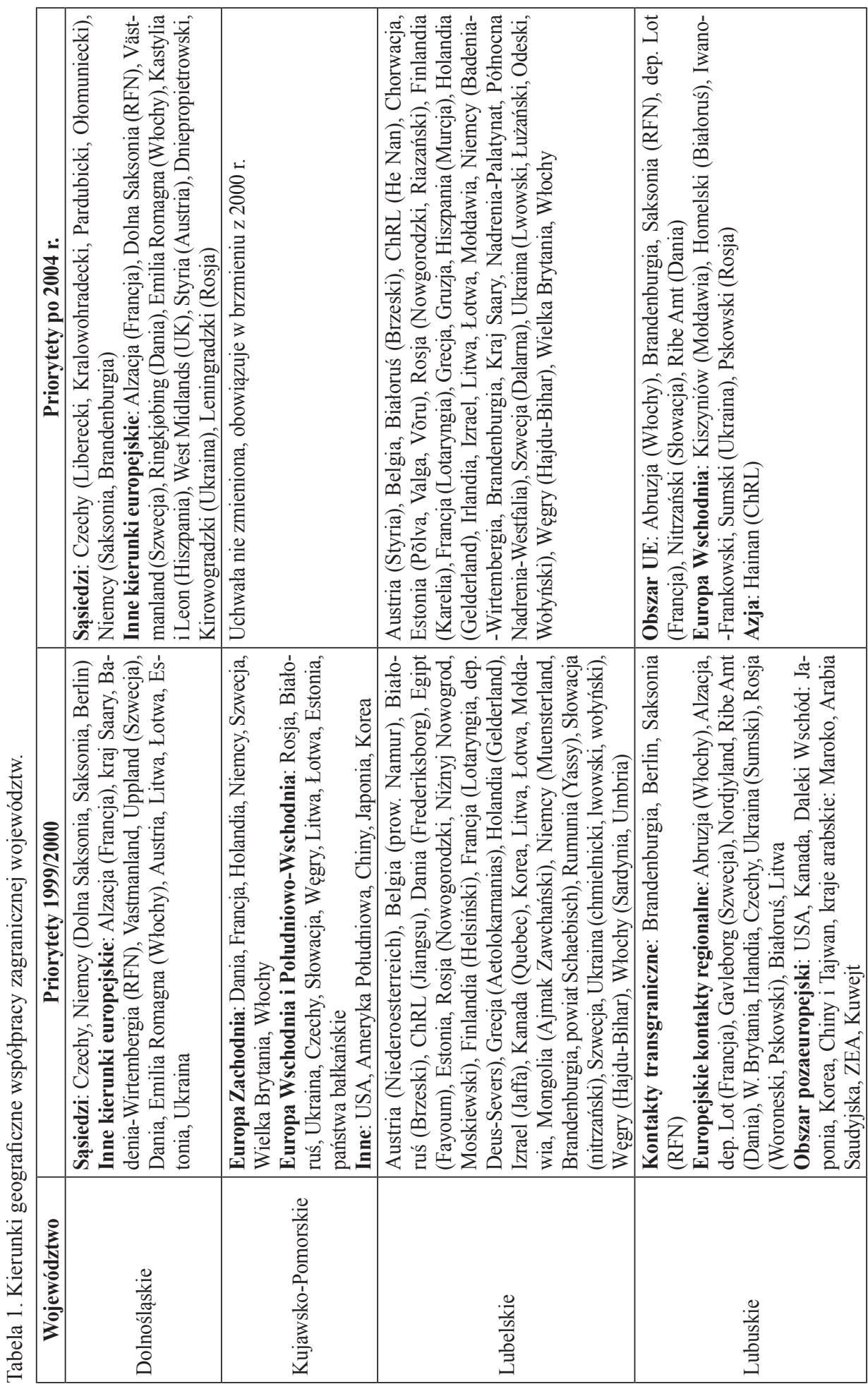




\begin{tabular}{|c|c|c|c|c|}
\hline$\dot{\Xi}$ & 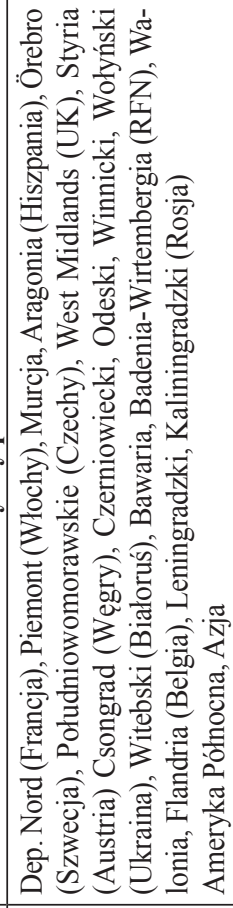 & 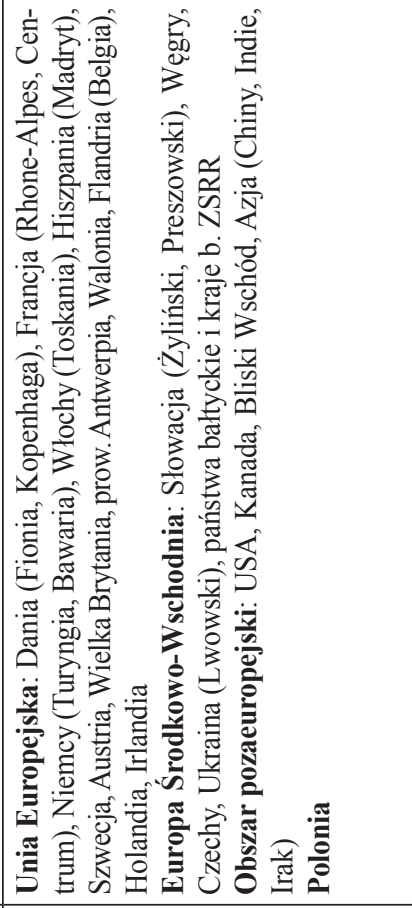 & 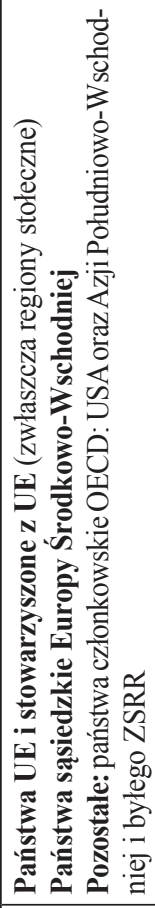 & 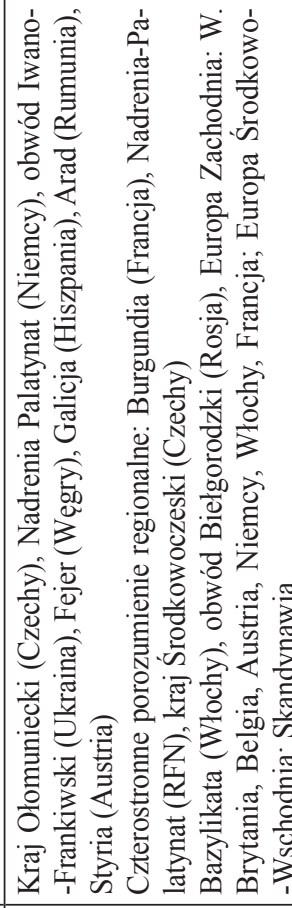 \\
\hline 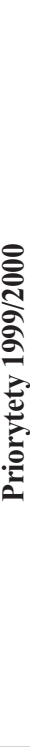 & 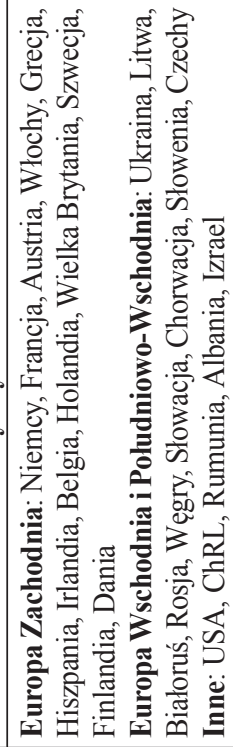 & 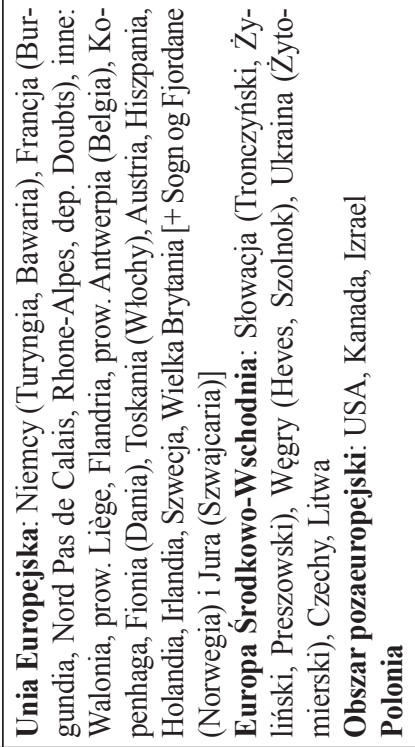 & 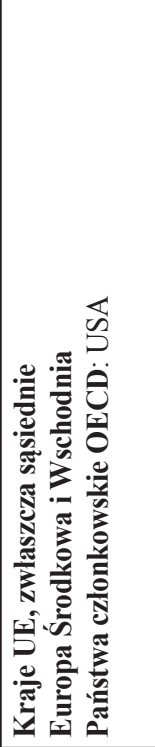 & 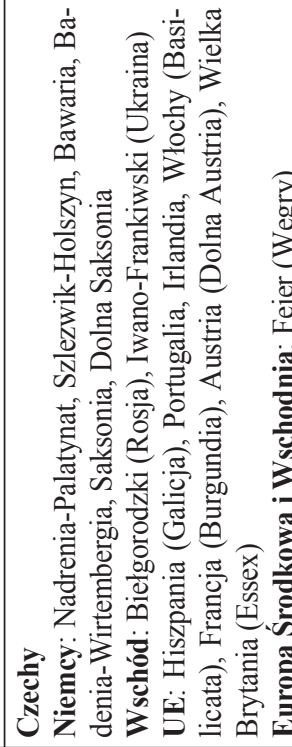 \\
\hline & لَّ & $\frac{0}{\frac{0}{0}}$ & 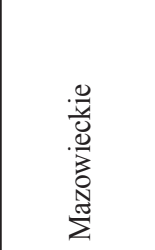 & \\
\hline
\end{tabular}




\begin{tabular}{|c|c|c|c|}
\hline & 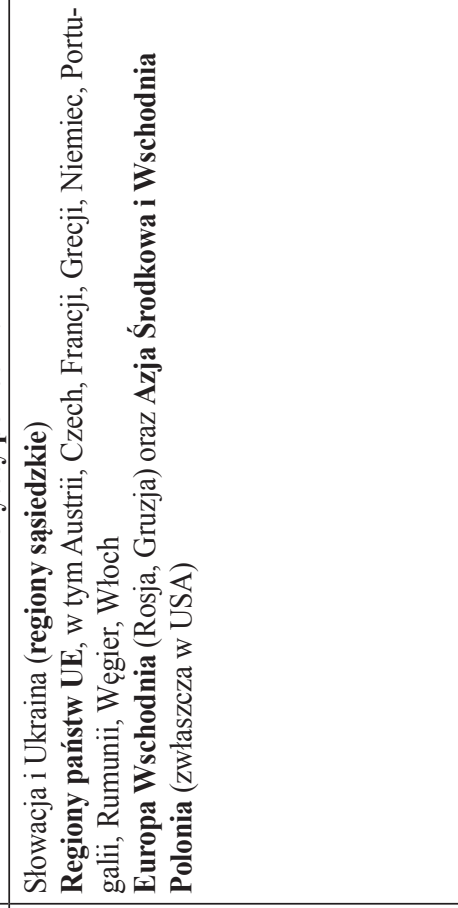 & 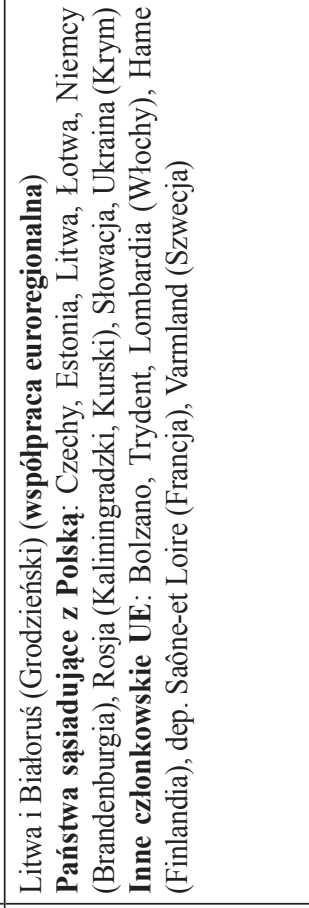 & 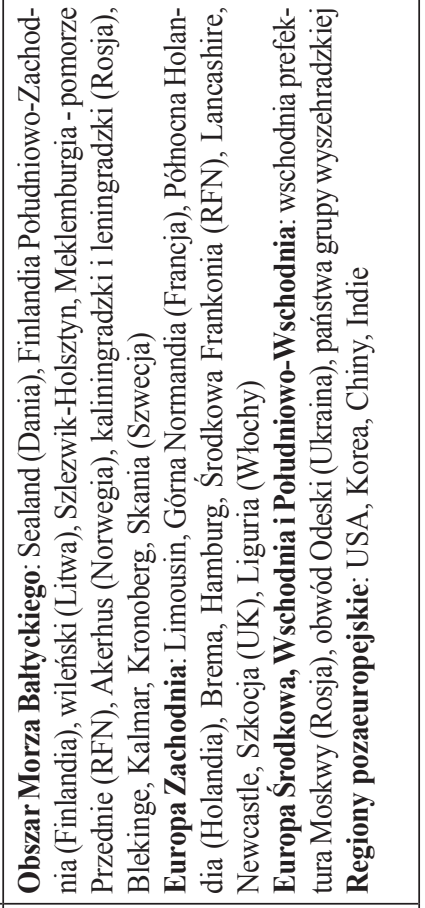 \\
\hline & 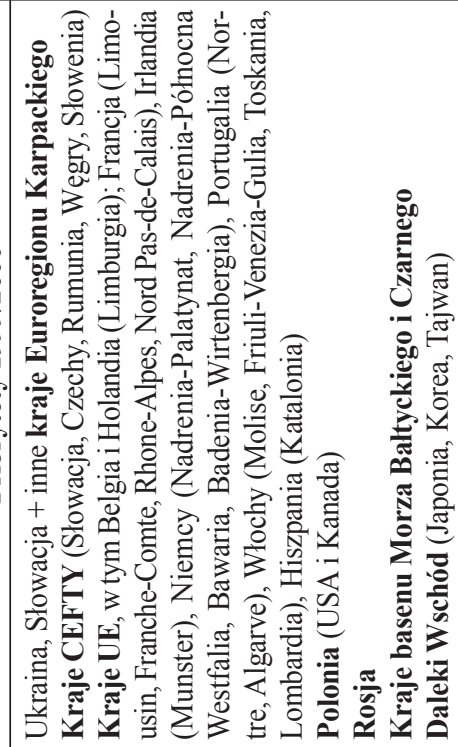 & 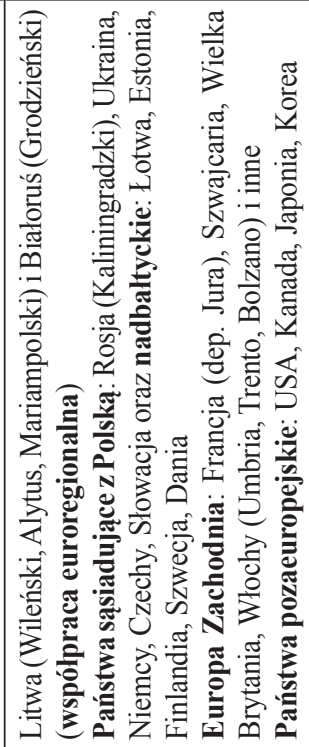 & 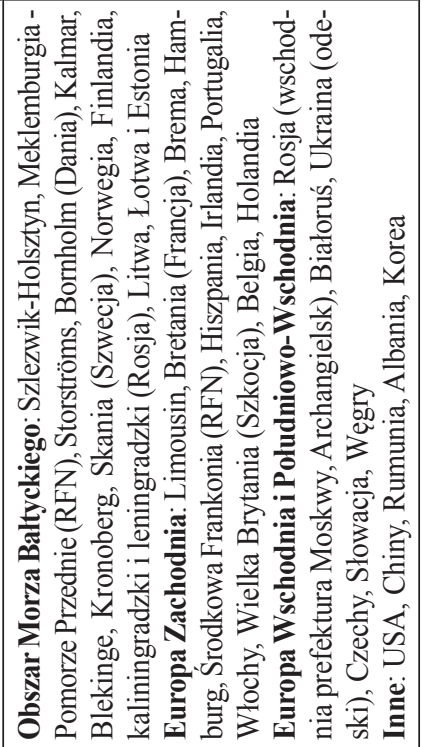 \\
\hline & 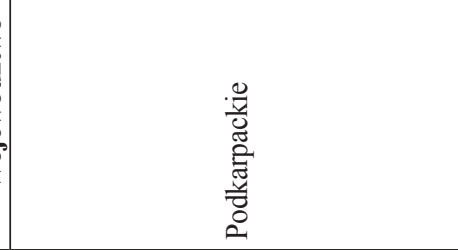 & & 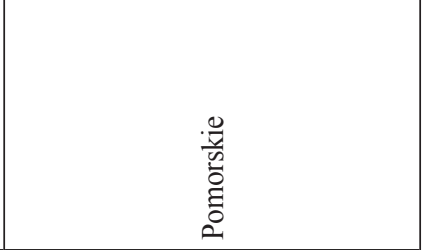 \\
\hline
\end{tabular}




\begin{tabular}{|c|c|c|c|c|}
\hline 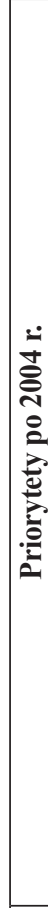 & 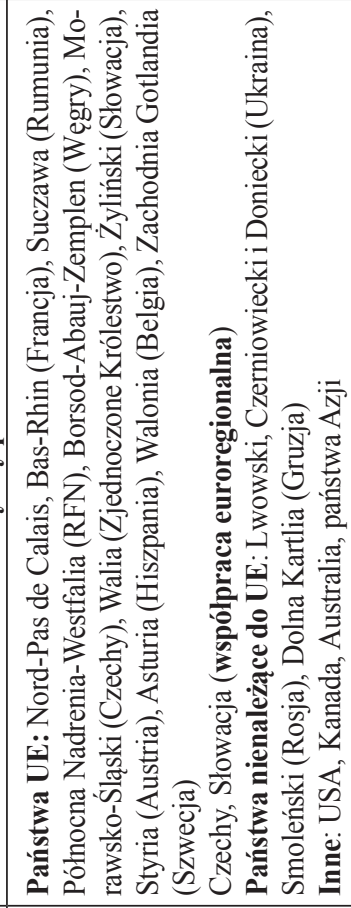 & 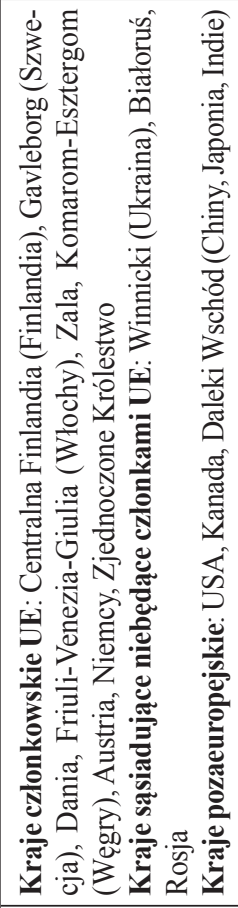 & 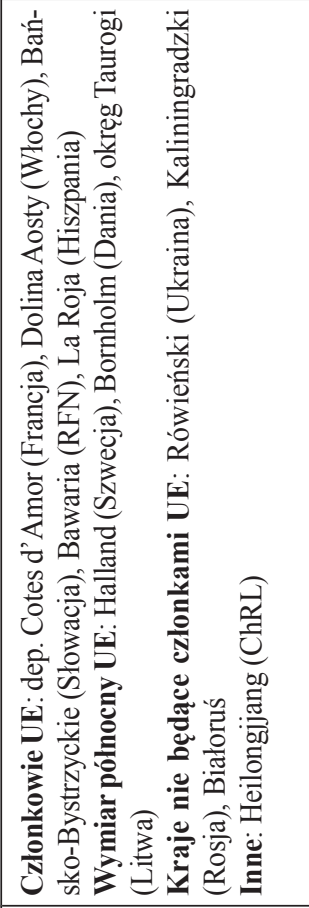 & 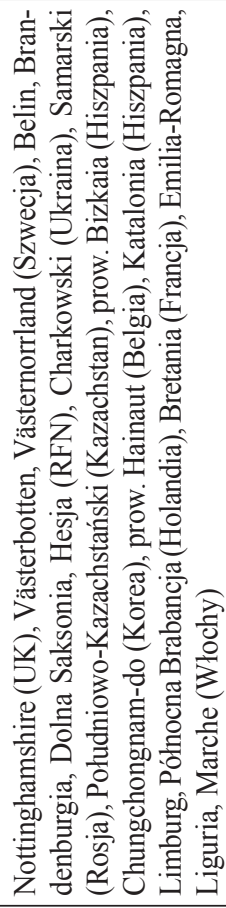 \\
\hline & 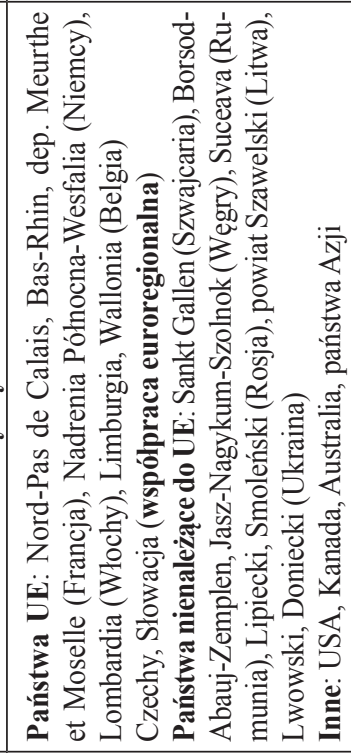 & 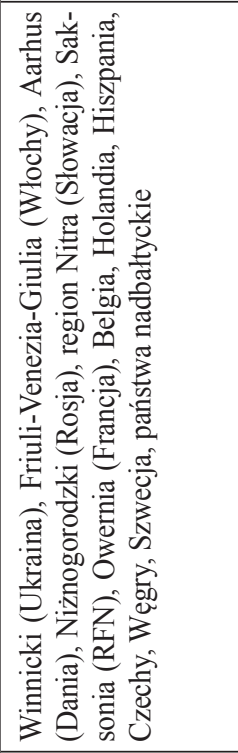 & 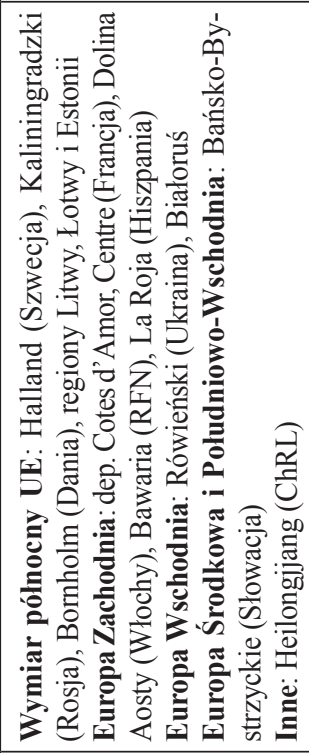 & 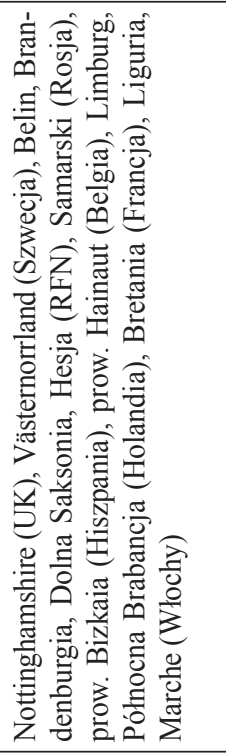 \\
\hline 这 & & 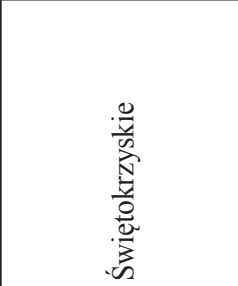 & 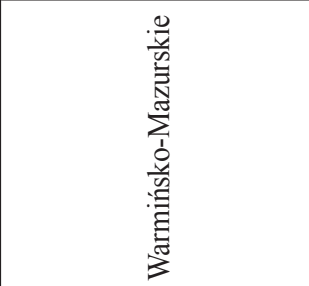 & \\
\hline
\end{tabular}




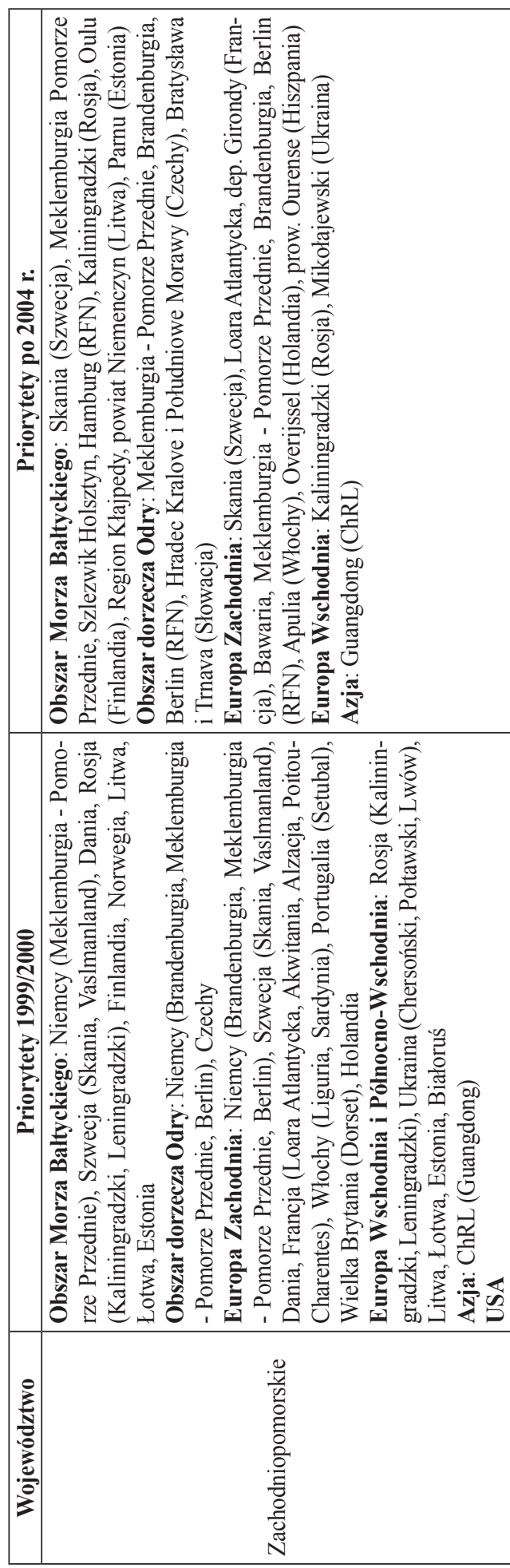

告

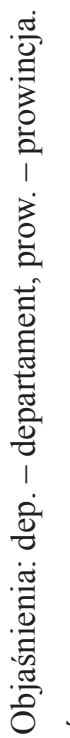

空

เี ฮี

预

।

. 
Tabela 2. Zamierzenia co do przystępowania do międzynarodowych zrzeszeń międzyregionalnych.

\begin{tabular}{|l|l|l|}
\hline \multicolumn{1}{|c|}{ Województwo } & \multicolumn{1}{c|}{ Priorytety 1999/2000 } & \multicolumn{1}{c|}{ Priorytety po 2004 r. } \\
\hline Dolnośląskie & AER, AEBR & Odra-Dunaj-Łaba \\
\hline Kujawsko-Pomorskie & AER, CEMR & Uchwała nie zmieniona po 2004 r. \\
\hline Lubelskie & $\begin{array}{l}\text { AEBR (poprzez euroregion Bug), } \\
\text { AER }\end{array}$ & AEBR, AER \\
\hline Lubuskie & Brak wskazań & AER, CEMR, VRF, CETC \\
\hline Łódzkie & AER, CEMR & AER, ERRIN, LMP, TRN \\
\hline Małopolskie & AER & AER, ERIS@ \\
\hline Mazowieckie & AER, CEMR & AER \\
\hline Opolskie & AER & ARGE \\
\hline Podkarpackie & AER & AER \\
\hline Podlaskie & AER, BSSSC, CEMR, AEBR & $\begin{array}{l}\text { AER, BSSSC, CEMR, AEBR, } \\
\text { CPMR, NEEBOR }\end{array}$ \\
\hline Pomorskie & $\begin{array}{l}\text { BSSSC, CPRM, AER, CEMR, } \\
\text { AEBR }\end{array}$ & $\begin{array}{l}\text { BSSSC, CPRM, AER, AEBR, } \\
\text { BDF, Forum PPB }\end{array}$ \\
\hline Śląskie & AER, CEMR & $\begin{array}{l}\text { AER, CEMR, ERIS@, RETI, } \\
\text { ERIH }\end{array}$ \\
\hline Świętokrzyskie & AER & AER, ERIS@ \\
\hline Warmińsko-Mazurskie & AER & $\begin{array}{l}\text { BSSSC, Europejska Sieć } \\
\text { Dziedzictwa Kulinarnego, AEBR }\end{array}$ \\
\hline Wielkopolskie & Brak wskazań & Brak wskazań \\
\hline Zachodniopomorskie & AEBR, AER, BSSSC & $\begin{array}{l}\text { AER, BSSSC, CETC, BDF, VRF, } \\
\text { ERIS@ }\end{array}$ \\
\hline
\end{tabular}

Źródło: Opracowanie własne na podstawie uchwał sejmików w sprawie priorytetów współpracy zagranicznej województw. 